\title{
A note on Pteris vittata L. (Pteridaceae) in Montenegro
}

\author{
WALTER GUTERMANN* \\ Department of Biogeography, Faculty Centre of Biodiversity, University of Vienna, \\ Rennweg 14, A-1030 Vienna, Austria
}

\begin{abstract}
Pteris vittata, formerly doubtfully indicated for Dalmatia, is recorded for Montenegro based on a hitherto disregarded collection preserved in the Vienna University herbarium.
\end{abstract}

Key words: Pteris vittata, Pteridophyta, fern, flora, Montenegro

\section{Introduction}

Pteris vittata L. (Pt. longifolia auct. non L. s. str. - cf. WALKER 1964, 1993; TRYON and TRYON 1982) is a subtropical fern of the Old World, with disjunct outliers in the southern Mediterranean. Additionally, a few naturalizations in Europe are known further north (cf. JALAS and SUOMINEN 1972). In the literature of the $19^{\text {th }}$ century it was indicated also for Dalmatia, e.g. in an authoritative survey of European ferns (MILDE 1867), although without any source adduced. Probably this author took the record from HoOKER $(1858,157$; HOOKER and BAKER 1868: 154), who had mentioned a specimen of his herbarium from Dalmatia (leg. Alexander). This was also the opinion of LUERSSEN (1889), who asked for a confirmation, however, since the species was missing in all the geographically pertinent literature (e.g. Schlosser and Vukotinović 1869). From that time this record, never localized in more detail, obviously was suppressed (HAYEK 1927 ff.) nor in the Analitička Flora Jugoslavije (MAYER and HORVATIĆ 1967) was it found worthy of consideration. In consequence no record for the former Yugoslavia is found in either Flora Europaea or in the Med-Checklist (WALKER 1964, 1993; GreuTER et al. 1984). In Atlas Florae Europaeae, the distribution map for Pteris vittata shows Zakinthos as the northernmost dot in the eastern Mediterranean (JALAS and SUOMINEN 1972: 56, map no. 60).

\section{Results and discussion}

In connection with floristic work on the Ionian islands (Greece), and examining vouchers from the island of Zakinthos in the Vienna University herbarium (WU), I unexpectedly

\footnotetext{
* Corresponding author, e-mail: walter.gutermann@univie.ac.at Copyright $^{\circledR} 2012$ by Acta Botanica Croatica, the Faculty of Science, University of Zagreb. All rights reserved.
} 


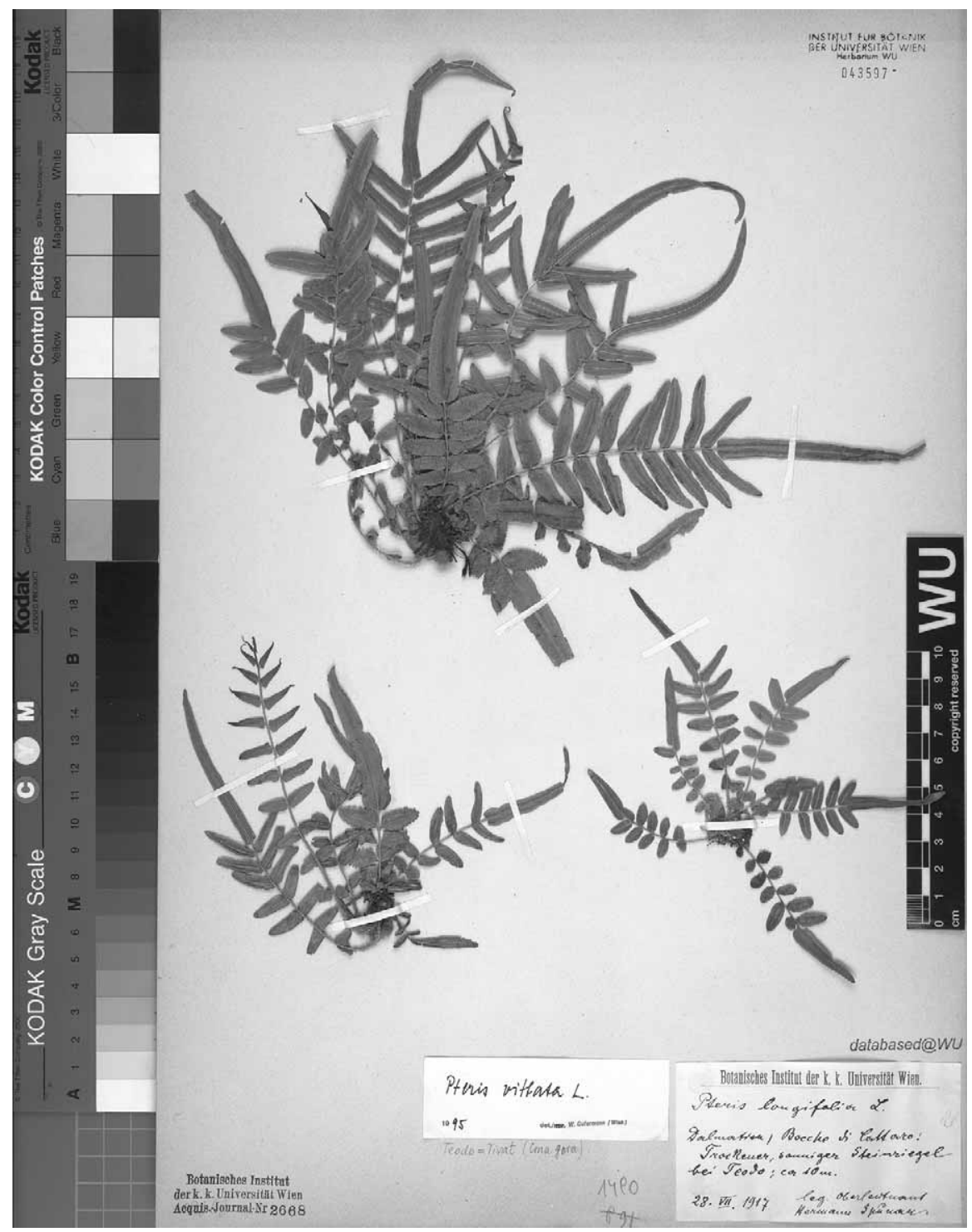

Fig. 1. Voucher specimen of Pteris vittata from Boka Kotorska (Herbarium WU).

came across a well preserved collection of Pteris vittata from Kotor Bay (Boka Kotorska; fig. 1), Montenegro. This affords a late corroboration of an old indication, and, thanks to the statements on the herbarium label, it allows an exact localisation of this occurrence, decidedly the northernmost in the Mediterranean east of Italy. The plants were collected on July, 28, very probably in 1916 [and not 1917 - see below], in (then) southern Dalmatia: , »Bocche di Cattaro: trockener, sonniger Steinriegel bei Teodo, ca. $10 \mathrm{~m}$ «, that is near Tivat (Grid 34TCN2 of Atlas Florae Europaeae), today part of Montenegro. The fern has not previously been recorded for this country (cf. ROHLENA 1942, PULEVIĆ 2005). 
The collection was incorporated into the WU herbarium in 1917, on June 22 (according to the Acquisitions Journal of the University herbarium), as the donation of Dr. A. Ginzberger, at that time (1903-1912)»Adjunkt « at the Botanical Institute of the Vienna University (SCHÖNBECK-TEMESY 1992). So far it remains uncertain, whether all collections of this entry (»24 Pflanzen aus Süd-Dalmatien«) came from H. Spunar, who collected the fern under discussion. - There is a discrepancy in relation to the collection date as written on the herbarium label (»28. VII. 1917«): presumably 1917 is an error for 1916, because the entries in the herbarium daybook were listed continuously by day.

So far, any other possible connections of the collector, Hermann Spunar, to botany in Vienna are unknown to us, as are further herbarium sheets traceable to him. According to information from Heeresgeschichtliches Museum (Vienna), Hermann Spunar (born in 1889 at Schota near Leibnitz, Styria) was first lieutenant of the fortress artillery, regiment no. 5, at that time stationed at Kotor for defence of the »k. u. k. Kriegshafen « (imperial naval port).

\section{Acknowledgements}

Investigations on the flora and vegetation of the Ionian islands have been supported by FWF (Fonds zur Förderung der wissenschaftlichen Forschung; Projekt P10466-BIO). The author is furthermore indebted to Dr. Wolfgang Etschmann (Heeresgeschichtliches $\mathrm{Mu}-$ seum) who kindly conveyed data on H. Spunar, and to Dr. Heimo Rainer (Herbarium WU) who provided the herbarium image.

\section{References}

Greuter, W., Burdet, H. M., Long, G. (eds.), 1984: Med-Checklist. A critical inventory of vascular plants of the circum-mediterranean countries, 1: Pteridophyta 2, Gymnospermae, Dicotyledones (Acanthaceae-Cneoraceae). Conservatoire et Jardin botanique de la Ville de Genève, Genève.

HayeK, A., 1927: Prodromus Florae peninsulae Balcanicae. 1. Band: Pteridophyta, Gymnospermae, Dicotyledoneae (Apetalae et Choripetalae). Repertorium specierum novarum regni vegetabilis 30, 1, 1-1193.

Hooker, W. J., 1858: Species filicum, being descriptions of the known ferns, 2. W. Pamplin, London.

Hooker, W. J., BAKer, J. G., 1868: Synopsis filicum, a synopsis of all known ferns. R. Hardwicke, London.

Jalas, J., Suominen, J. (eds.) 1972: Atlas Florae Europaeae. Distribution of vascular plants in Europe. 1. Pteridophyta (Psilotaceae to Azollaceae). The Commitee for Mapping the Flora of Europe and Societas Biologica Fennica Vanamo, Helsinki.

Luerssen, CH., 1889: Die Farnpflanzen oder Gefässbündelkryptogamen (Pteridophyta). [Dr. L. Rabenhorst's Kryptogamenflora von Deutschland, Oesterreich und der Schweiz, 2, 3], E. Kummer, Leipzig. 
Mayer, E., Horvatić, S., 1967: I. Pteridophyta (Ferns). In: Horvatić, S. (ed.), Flora analytica Iugoslaviae (In Croatian), 1, 1, 81-155. Institut za botaniku sveučilišta u Zagrebu, Zagreb.

Milde, J., 1867: Filices Europae et Atlantidis, Asiae minoris et Sibiriae. A. Felix, Lipsiae.

Pulević, V., 2005: Material for vascular flora of Montenegro. A supplement to »Conspectus Florae Montegrinae«(J. Rohlena) (in Montenegrin). Republički zavod za zaštitu prirode Crne Gore, Podgorica.

RohlenA, J., 1942: Conspectus florae Montenegrinae. Preslia 20/21, 1-506.

Schlosser, J. C., Vukotinović, L., 1869: Flora Croatica exhibens stirpes phanerogamas et vasculares cryptogamas quae in Croatia Slavonia et Dalmatia sponte crescunt nec non. F. Župan, Zagrabiae.

SchÖnBECK-Temesy, E., 1992: Zur Geschichte des Herbars der Wiener Universität. In: Morawetz, W., (Ed.), Die Botanik am Rennweg. Das Institut für Botanik und der Botanische Garten der Universität Wien. Festband zur Eröffnung des neuen Instituts. Abhandlungen der Zoologisch-Botanischen Gesellschaft in Österreich 26, 69-95.

Tryon, R. M., TrYon, A. T., 1982: Ferns and allied plants. With special reference to tropical America. Springer-Verlag, New York, Heidelberg, Berlin.

Walker, T. G., 1964: 1. Pteris L. In: Tutin, T. G., Heywood, V. H., Burges, N. A., Valentine, D. H., Walters, S. M., Webb, D. A. (Eds) with the assistance of BALl, P. W., Chater, A. O.), Flora Europaea 1, 11. University Press, Cambridge.

Walker, T. G., 1993: Pteris L. In: Tutin, T. G., Burges, N. A., Chater, A. O., Edmondson, J. R., Heywood, V. H., Moore, D. M., Valentin, D. H., Walters, S. M., WebB, D. A. (eds., assisted by AKERoyd, J. R., Newton, M. E.), Flora Europaea 1, 14. University Press, Cambridge. 